\title{
Psychological characteristics versus swallowing and speech rehabilitation efficiency in patients after oral cavity cancer excision
}

\section{Profil psychologiczny a efektywność rehabilitacji połykania i mowy chorych po wycięciu nowotworu jamy ustnej}

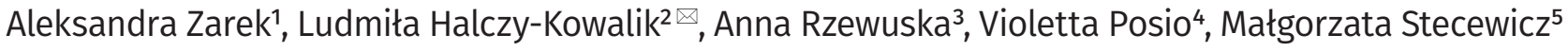 \\ ${ }^{1}$ Uniwersytet Medyczny im. Piastów Śląskich we Wrocławiu, Zakład Humanistycznych Nauk Lekarskich, ul. J. Mikulicza-Radeckiego 7, 50-368 Wrocław \\ 2 Pomorski Uniwersytet Medyczny w Szczecinie, Samodzielna Pracownia Rehabilitacji Pooperacyjnej Chirurgii Szczękowo-Twarzowej, ul. Unii Lubelskiej 1, 71-252 Szczecin \\ ${ }^{3}$ Pomorski Uniwersytet Medyczny w Szczecinie, Klinika Chirurgii Szczekowo-Twarzowej, ul. Unii Lubelskiej 1, 71-252 Szczecin \\ ${ }^{4}$ Pomorski Uniwersytet Medyczny w Szczecinie, Zakład Diagnostyki Obrazowej i Radiologii Interwencyjnej, ul. Unii Lubelskiej 1, 71-252 Szczecin \\ ${ }^{5}$ Uniwersytet Szczeciński, Katedra Pedagogiki Specjalnej, ul. Krakowska 71-79, 71-017 Szczecin \\ $\triangle$ sprpchst@pum.edu.pl
}

\begin{abstract}
Introduction: Personality traits of the patients surgically treated due to oral cancer form anxiety and depression levels associated with body deformation, as well as life quality during illness, and they are also associated with life span of the patients. It is purposeful to take personality traits into account during treatment management and rehabilitation of the patients.

The aim of work is to recognize the association between personality traits and functional rehabilitation course in the patients treated due to oral cancer.

Materials and methods: 100 patients ( $W-42, M-58 ; 55.78$ \pm 11.68 years) surgically treated due to oral cavity squamous carcinoma. Patients participated in the rehabilitation of oral functions. Wound healing course, postoperative facial deformity, breathing, swallowing, and speech were assessed in relation to "self-image", "body image", and "the level of acceptance of the disease" according to the Adjective Check List ACL-37, Body Cathexis Scale, and Illness Acceptance Scale after 2, 4, and 12 weeks post-surgically.
\end{abstract}

Results: Greater swallowing efficiency after 4 weeks post-surgically was present in patients with a stronger need for order and endurance. Patients who achieved greater speech efficiency in the $4^{\text {th }}$ week post-surgically accepted their illness in a greater part. Patients in whom post-surgical deformity was greater showed lesser intensity in: achievements, domination, endurance, self-exposure, spontaneity in interpersonal contacts. These patients are characterized with lower self-reliance and greater need for counselling.

Conclusions: Different personality traits of patients at different stages of rehabilitation are of importance. Patients with greater post-surgical deformities need special support. Psychological assessment simplifies the selection of the rehabilitating patients who need particular support in the range of building motivation for functional rehabilitation, and developing social skills which simplify illness adaptation.

Keywords: oral cavity cancer; swallowing disturbances; speech disturbances; face deformity; rehabilitation; personality traits.

\begin{abstract}
ABSTRAKT
Wstęp: Cechy osobowości chorych operowanych z powodu nowotworu jamy ustnej kształtują poziom lęku i depresji związanych z deformacją ciała oraz jakość życia w chorobie, a także są związane z czasem przeżycia chorych. Konieczne jest ich uwzględnianie przy planowaniu leczenia oraz rehabilitacji osób chorych.

Celem pracy było poznanie związku między właściwościami osobowościowymi a przebiegiem rehabilitacji czynnościowej u chorych leczonych z powodu nowotworu jamy ustnej.

Materiały i metody: W badaniu wzięło udział 100 chorych 42 kobiety i 58 mężczyzn $(55,78 \pm 11,68$ lat) operowanych z powodu raka płaskonabłonkowego jamy ustnej. Chorzy uczestniczyli w rehabilitacji funkcji jamy ustnej. Oceniano przebieg gojenia zniekształcenie pooperacyjne twarzy, sprawność oddychania, połykania i mowy w odniesieniu do „obrazu siebie”, „obrazu ciała” i „poziomu akceptacji choroby” wg Adjective Check List ACL-37, Body Cathexis Scale i Illness Acceptance Scale po upływie 2, 4 i 12 tyg. od zabiegu operacyjnego.
\end{abstract}

Wyniki: Większą sprawność połykania po upływie 4 tyg. od operacji uzyskiwały osoby cechujące się silniejszą potrzebą porządku i wytrwałości, większą sprawność mowy - osoby, które bardziej akceptowały chorobę. Pacjenci, u których poziom zniekształcenia pooperacyjnego był większy, ujawnili mniejsze natężenie wybranych potrzeb: osiągnięć, dominacji, wytrwałości i ujawniania siebie, jak również mniejszą spontaniczność w kontaktach interpersonalnych. Osoby te miały mniejsze zaufanie do siebie i większą potrzebę uzyskania porady w celu dokonania zmian w życiu. Wnioski: Na różnych etapach rehabilitacji znaczenie mają odmienne właściwości osobowości pacjentów. Szczególnego wsparcia wymagają chorzy doświadczający większego zniekształcenia pooperacyjnego. Ocena psychologiczna ułatwia wyłonienie z grupy rehabilitowanych chorych osób wymagających silniejszego wsparcia w zakresie budowania motywacji do rehabilitacji czynnościowej oraz rozwijania umiejętności społecznych ułatwiających adaptację do choroby.

Słowa kluczowe: rak jamy ustnej; zaburzenia połykania; zaburzenia mowy; zniekształcenie twarzy; rehabilitacja, cechy osobowości. 


\section{INTRODUCTION}

Patients in whom a malignant tumour localized in the oral cavity area was diagnosed and radically excised are in a very difficult medical as well as psychological situation. Their lives may still be threatened despite the fact they had been subjected to a distorting surgery and complementary radiotherapy. After the surgery patients may experience various functional deficits in terms of breathing, chewing, swallowing, and speech, as well as psychological and social problems due to their disability or unfavourable appearance to a varying degree $[1,2,3,4,5,6]$. These are often accompanied by the fear of recurrence [7].

Even minor face distortion due to the surgery is a strong traumatizing factor since it is associated with the key-area of the body responsible for the sense of identity of the patient, who is socially exposed and evaluated $[8,9]$. An additional problem is the fact that the change in appearance is sudden, and sometimes irreversible [10].

Swallowing and speech rehabilitation in patients serves as functional disturbances alleviation, and also supports the psychological acceptance of a new life situation.

Effective swallowing and speech rehabilitation after a radical oral cavity tumour excision followed by the excised structures' restoration may improve the patients' quality of life. During the process, the key-element for the patient is to decide to make the effort of rehabilitation, and especially to continue it despite the lack of immediate effects. According to research, patients' personality traits, along with some other factors, contribute to the occurrence of oral cavity neoplasm [11], moderate the anxiety and depression levels which are associated with body deformation [12], shape their quality of life during the disease, and are even associated with their life-span [13, 14]. Therefore, it is recommended to take the patients' personality traits into account in treatment planning as well as during rehabilitation [1].

The research aims to identify the relationship between the personality traits of patients treated due to oral cavity tumour and their functional rehabilitation course. In particular, the aim of the research is to answer three research questions:

1. What is the relationship between personality traits and swallowing and speech efficiency in patients during different stages of rehabilitation?

2. Is there any relationship between the illness acceptance level, swallowing and speech efficiency, and the level of postsurgical distortion?

3. What is the relationship between the level of post-surgical distortion and the self-perception in patients?

\section{MATERIALS AND METHODS}

The study protocol was approved by the Bioethical Commission of The Pomeranian Medical University in Szczecin (PMU) in Poland. The selection of the patients for the research was purposeful. The main criterion of inclusion
Chorzy, u których rozpoznano, a następnie radykalnie wycięto nowotwór złośliwy jamy ustnej, znajdują się w szczególnie trudnej sytuacji medycznej i psychologicznej. Ich życie wciąż może być zagrożone pomimo tego, iż poddali się okaleczającej operacji i uzupełniającej radioterapii. Po zabiegu operacyjnym w różnym stopniu doświadczają deficytów funkcjonalnych w zakresie oddychania, żucia, połykania i mowy, a także trudności psychologicznych i społecznych związanych z niepełnosprawnością oraz zmienionym wyglądem twarzy $[1,2,3,4$, 5, 6]. Często towarzyszy temu lęk przed nawrotem choroby [7].

Nawet nieznaczne zniekształcenie twarzy będące wynikiem operacji stanowi silny czynnik traumatyzujący, dotyczy bowiem obszaru ciała kluczowego dla poczucia tożsamości osoby chorej, podlegającego ekspozycji i ewaluacji społecznej [8, 9]. Dodatkową trudność stanowi fakt, iż zmiana wyglądu jest nagła, a niekiedy nieodwracalna [10].

Rehabilitacja połykania i mowy operowanych pacjentów służy złagodzeniu zaburzeń funkcjonalnych, a ponadto wspomaga proces adaptacji psychologicznej do nowej sytuacji życiowej. Efektywna rehabilitacja po radykalnym wycięciu nowotworu jamy ustnej, z następowym odtworzeniem wyciętych struktur, może poprawić jakość życia chorych. W tym procesie kluczowym elementem jest podjęcie przez pacjenta wysiłku rehabilitacji, a zwłaszcza kontynuowanie jej pomimo braku natychmiastowych efektów. Z wyników przeprowadzonych badań wynika, iż cechy osobowości pacjentów wspólnie z innymi czynnikami przyczyniają się do wystąpienia nowotworu jamy ustnej [11], moderują poziom lęku i depresji związanych z deformacją ciała [12], kształtują jakość życia w chorobie, a nawet są związane z czasem przeżycia chorych [13, 14]. Dlatego zaleca się, aby brać pod uwagę właściwości osobowości osób chorych zarówno przy planowaniu ich leczenia, jak i rehabilitacji [1].

Praca miała na celu poznanie związku między właściwościami osobowościowymi a przebiegiem rehabilitacji czynnościowej u chorych leczonych z powodu nowotworu jamy ustnej. W szczególności celem pracy było uzyskanie odpowiedzi na trzy pytania badawcze:

1. Jaki związek istnieje pomiędzy właściwościami osobowości a sprawnością połykania i mowy u chorych na różnych etapach rehabilitacji?

2. Czy poziom akceptacji choroby ma związek ze sprawnością połykania i mowy oraz stopniem zniekształcenia pooperacyjnego?

3. Jaki związek istnieje pomiędzy poziomem zniekształcenia pooperacyjnego a percepcją własnej osoby u tych chorych?

\section{MATERIAŁY I METODY}

Projekt badania uzyskał pozytywną opinię Komisji Bioetycznej Pomorskiego Uniwersytetu Medycznego w Szczecinie (PUM). Dobór osób do badań miał charakter celowy. Objęto nimi chorych operowanych z powodu raka płaskonabłonkowego jamy ustnej w Klinice Chirurgii Szczękowo-Twarzowej PUM, którzy 
was performed squamous cell oral cavity carcinoma excision in patients of the Maxillo-Facial Surgery Clinic of PMU, and written consent for the psychological examination, surveys, and examination outcomes publication. Lack of consent for the psychological examination and surveys excluded the patient from the study. A total of 100 patients were included: 42 women and 58 men, aged between 23 and 80 (mean age: 55.78 years; standard deviation: 11.68 years).

All of the patients were subjected to swallowing and speech rehabilitation in the early post-surgical stage. The patients were informed on the possibility of disturbed oral cavity functions due to the surgical improvement, rehabilitation, as well as complementary radiotherapy before the surgery. Since in $2 / 3$ of the patients radiotherapy was necessary within the period of 4-6 weeks post-surgically, swallowing and speech rehabilitation was begun as early as possible (with the necessary time for wound healing taken into account) in order to obtain the best possible therapeutic effect up to the therapy beginning time.

At the beginning of swallowing rehabilitation the patients were persuaded to exercise planned saliva swallowing; the second day post-surgically the patients were asked to swallow saliva every hour. After the healing of face layer wounds the patients were asked to perform exercises improving oral fissure sealing. After 2 weeks post-surgically a video radiological examination of the swallowing was performed in the patients with a risk of aspiration. The swallowing act course was analyzed in accordance with the model described by Dodds, Stewart and Logemann $[15,16]$.

Speech rehabilitation was commenced after surgical wounds healing, with saliva swallowing at any moment, and exercises improving the efficiency of the three circular muscles: orbicularis oris muscle tightening, pallato-lingual tightening, and lingual-pharyngeal tightening, exercises enhancing motion activity of the tongue, lips, and cheeks. The patients were supported in finding articulatory substitutes.

Level of wound healing, breathing, swallowing, and speech disturbances, as well as face distortion level were assessed with the use of a 4-point scale, in which 1 point was scored for the highest performance of the assessed function; 2 and 3 points were scored for intermediate levels; 4 points were scored for the lowest level of performed functions. Healing course and face distortion assessment was performed 2 weeks post-surgically; breathing, swallowing, and speech assessment was performed after 2, 4 and 12 weeks post-surgically.

Psychological examination was performed in the patients 2 weeks post-surgically. Psychological assessment involved visual self-assessment of the patients as well as visual assessment of the affected patients' bodies, and the level of neoplasm acceptance.

Self-assessment of the patients was performed with the use of the Adjective Check List (ACL-37) by H.G. Gough and A.B. Heilbrun in the Polish version by Zenomena Płużek. ACL-37 enables patients to describe personality in different aspects. It contains 300 randomly ordered adjectives referring to various personality aspects. A patient's task is to choose the definitions which describe their personality best. The test is comprised wzięli udział w badaniu psychologicznym, uprzednio wyrażając pisemną zgodę zarówno na wypełnienie testów psychologicznych, jak i publikację uzyskanych wyników. Brak takiej zgody był kryterium wykluczającym. W badaniu uczestniczyło 100 osób, w tym 42 kobiety i 58 mężczyzn w wieku 23-80 lat (średni wiek 55,78 lat, odchylenie standardowe - 11,68 lat).

Wszystkich chorych poddano w okresie wczesnopooperacyjnym rehabilitacji połykania i mowy (o możliwości poprawy funkcji jamy ustnej, zaburzonych w wyniku zabiegu operacyjnego, pacjenci byli informowani przed operacją). Jako że u $2 / 3$ pacjentów konieczne było zastosowanie naświetlań radiologicznych w okresie 4-6 tyg. po operacji, rehabilitację połykania i mowy rozpoczęto możliwie najwcześniej (z uwzględnieniem czasu niezbędnego do zagojenia się ran pooperacyjnych), tak aby do rozpoczęcia terapii radiologicznej uzyskać jak najlepsze efekty terapeutyczne.

Rehabilitację połykania rozpoczynano od skłonienia chorego do ćwiczenia planowego połykania śliny, od 2. doby po zabiegu operacyjnym chorego proszono o dokonywanie połknięć śliny co godzinę. Po wygojeniu ran powłok twarzy proszono chorego o wykonywanie ćwiczeń poprawiających szczelność szpary ust. Po upływie 2 tyg. od zabiegu operacyjnego wykonywano wideoradiologiczne badanie połykania u chorych, u których istniało zagrożenie aspiracją. Analizowano przebieg aktu połykania wg modelu opisanego przez Doddsa, Stewarta i Logemanna $[15,16]$.

Rehabilitację mowy rozpoczynano po wygojeniu ran operacyjnych, od ćwiczeń kontrolowanego bezdechu i połykania śliny w dowolnym momencie, ćwiczeń poprawiających sprawność trzech pierścieni mięśniowych: zwarcia mięśnia okrężnego ust, zwarcia podniebienno-językowego i językowo-gardłowego, ćwiczeń wzmagających aktywność ruchową języka, warg, policzków. Wspomagano chorego w znalezieniu zastępczych miejsc artykulacyjnych.

Poziom nieprawidłowości w przebiegu gojenia, oddychania, połykania i mowy oraz stopień zniekształcenia twarzy oceniano z zastosowaniem 4-punktowej skali, w której punkt 1 oznaczał najwyższy poziom wykonania funkcji, punkty 2 i 3 opisywały pośrednie poziomy, zaś punkt 4 wskazywał na najniższy poziom wykonania funkcji. Oceny przebiegu gojenia i zniekształcenia twarzy dokonywano po 2 tyg., natomiast oceny oddychania, połykania i wymowy po 2, 4 i 12 tyg. od zabiegu operacyjnego.

Badanie psychologiczne przeprowadzano u chorych po ok. 2 tyg. od zabiegu operacyjnego. Ocena psychologiczna obejmowała oszacowanie obrazu siebie i obrazu ciała chorych oraz poziom ich akceptacji choroby nowotworowej.

Pomiaru obrazu siebie dokonano za pomocą Testu Przymiotników ACL-37 (Adjective Check List) autorstwa H.G. Gougha i A.B. Heilbruna w opracowaniu Zenomeny Płużek. ACL-37 umożliwia opis osobowości w wielu aspektach. Zawiera 300 uporządkowanych losowo przymiotników odnoszących się do różnych aspektów osobowości, a zadaniem osoby badanej jest wybrać te określenia, które jej zdaniem najlepiej ją opisują. Test składa się z 5 części: I. Skale Modus operandi; II. Skale potrzeb; III. Skale tematyczne; IV. Skale analizy transakcyjnej; V. Skale oryginalności-inteligencji [17]. 
of five parts: I. Modus operandi; II. Needs scales; III. Thematic scales; IV. Transactional analysis scales; V. Originality - intelligence scales [17].

Body visual assessment was performed with the use of the Body Cathexis Scale (BCS) by P.F. Secord and S.J. Jourard [18]. The BCS includes a list of 54 body parts and their functions, which are listed in reversed alphabetical order, and it is comprised of two test sheets. When completing the BCS-1 test sheet, the patient shows their satisfaction level of particular elements of their body (from 1 - very dissatisfied, to 5 - very satisfied). In the BCS-2 test sheet, the patient shows the level of subjective meaning of these bodily features (from 1 - unimportant, to 5 - very important). Furthermore, the test enables body image analysis on the basis of S. Franzoi's concept, according to which the body may be viewed from two points: 1) physical appearance - how it is presented to others (BCS_Parts), or 2) way of functioning - how the body is functioning (BCS_Functions) [19]. On the basis of other research results, the following elements of body image were prescribed to the BCS_Parts: ears, back of the head, thorax, waist, neck, width of the shoulders, feet, arms, buttocks, back, breasts, fingers, legs, genital organs, wrists, shape of the head, ankles, knees, chest, hands, hips. Excretion, digestion, physical fitness, sleep, level of energy, breathing, appetite and sexual activity were included in BCS_ Functions [20]. One more indicator was included for the purpose of this research; BCS_Face included: teeth, mouth, face, face profile, face oval, chin, chin profile, eyes, nose, shape of jaw, cheek bones, forehead, skin complexion, eyebrows. On the whole, the body image of every patient was described by eight indicators, and each of them was calculated as an arithmetic mean of its components' assessments; four of the indicators showed the level of satisfaction with different bodily aspects (BCS1, BCS1_Functions, BCS1_Parts, BCS1_Face), and the other four were associated with the significance of these aspects (BCS2, BCS2_Functions, BCS2_Parts, BCS2_Face).

The level of acceptance was assessed on the basis of the Acceptance Illness Scale (AIS) by B.J. Felton, T.A. Ravenson, and G.A. Hinrichsen. The scale is used for testing patients. It includes 8 statements describing various negative consequences of a bad health condition (limitations due to an illness, inability to perform favourite activities, experiencing dependence on other people, among others), and a patient's task is to indicate the level of how a particular statement is true for themselves (where 1 means "I absolutely agree", and 5 means "I absolutely disagree"). The higher the score on the scale, the greater the illness acceptance [21].

The examined patients also filled in Information Cards on selected personal and demographic details (date of birth, education, marital status, height, weight). Name and surname details (known to the doctors) were replaced with identification code on the Cards.

\section{Statistical Analysis}

The normality of the variables distributions were checked with the use of the Kolmogorov-Smirnov test. Differences between mean results were checked with the use of the t-Student test.
Do badania obrazu ciała wykorzystano Kwestionariusz Obrazu Ciała (KOC) będący parafrazą Body Cathexis Scale autorstwa P.F. Secorda i S.J. Jourarda [18]. Test ten zawiera listę 54 części i funkcji ciała, które zorganizowane są w odwrotnym porządku alfabetycznym, i składa się z 2 arkuszy testowych. Wypełniając KOC-1, osoba badana wskazuje na stopień satysfakcji z poszczególnych elementów swojego ciała (od 1 - bardzo niezadowolony do 5 - bardzo zadowolony), natomiast wypełniając arkusz KOC-2, badany ujawnia poziom subiektywnego znaczenia przypisywanego tymże elementom własnej cielesności (od 1 - w ogóle nieważny do 5 - bardzo ważny). Ponadto test umożliwia analizę obrazu ciała w oparciu o koncepcję S. Franzoi, zgodnie z którą ciało można ujmować z 2 punktów widzenia: 1) wyglądu fizycznego, czyli tego, jak prezentuje się innym (KOC_Części), albo też 2) sposobu funkcjonowania, czyli tego, jak działa (KOC_Funkcje) [19]. Na podstawie wyników innego badania do skali KOC_Części przypisano następujące elementy obrazu ciała: uszy, tył głowy, tułów, talia, szyja, szerokość barków, stopy, ramiona, pośladki, plecy, piersi, palce dłoni, nogi, narządy płciowe, nadgarstki, kształt głowy, kostki, kolana, klatka piersiowa, dłonie, biodra. Z kolei do skali KOC_ Funkcje włączono: wydalanie, trawienie, sprawność fizyczną, sen, poziom energii, oddychanie, apetyt, aktywność seksualną [20]. Na potrzeby niniejszej pracy wyodrębniono jeszcze jeden wskaźnik - KOC_Twarz, którego składowymi były: zęby, usta, twarz, profil twarzy, owal twarzy, broda, profil brody, oczy, nos, kształt szczęki, kości policzkowe, czoło, cera, brwi. W sumie obraz ciała każdej osoby badanej opisywany był przez 8 wskaźników, z których każdy obliczany był jako średnia arytmetyczna z ocen jego składowych - 4 wskazywały na poziom zadowolenia z różnych aspektów cielesności (KOC1, KOC1_Funkcje, KOC1_Części, KOC1_Twarz), a 4 dotyczyły znaczenia przypisywanego tymże aspektom ciała (KOC2, KOC2 Funkcje, KOC2_Części, KOC2_Twarz).

Poziom akceptacji choroby określono na podstawie wyników Skali Akceptacji Choroby, będącej polską adaptacją testu Acceptance Illness Scale (AIS), którego autorami byli B.J. Felton, T.A. Ravenson i G.A. Hinrichsen. Skala ta służy do badania osób chorych. Zawiera 8 stwierdzeń opisujących różne negatywne konsekwencje złego stanu zdrowia (m.in. ograniczenia wynikające z choroby, niemożność wykonywania ulubionych aktywności, doświadczanie zależności od innych osób), a zadaniem osoby badanej jest wskazanie, w jakim stopniu te treści opisują jej stan (od 1 - zdecydowanie się zgadzam do 5 - zdecydowanie się nie zgadzam). Wyższy wynik w skali wskazuje na większą akceptację choroby [21].

Osoby badane wypełniały także kartę informacyjną dotyczącą wybranych danych osobowych i demograficznych (data urodzenia, wykształcenie, stan cywilny, wzrost, waga). Informację o nazwisku i imieniu pacjenta (znanych lekarzowi) zastąpiono w karcie kodem identyfikacyjnym.

\section{Statystyczna analiza danych}

Normalność rozkładów badanych zmiennych sprawdzano testem Kołmogorowa-Smirnowa. Różnice pomiędzy średnimi wynikami sprawdzano za pomocą testu t-Studenta. W celu 
Spearman's Rank-Order Correlation was used to compare the relationship between the variables. In the analysis the level of significance was $\mathrm{p}<0.05$. Statistical analysis was performed with the use of relevant calculation models of Stata 11.

\section{RESULTS}

\section{Clinical assessment}

Tumour characteristics, with its location, stage, and treatment modalities in the patients, are presented in Table 1.

In the analyzed group of patients the most common surgery indication was tongue tumour (in more than $1 / 4$ of the patients); more than a half of the patients were treated surgically due to the tumour in the III and IV clinical stages; $2 / 3$ of the patients were treated surgically with following radiotherapy. The range of surgery in the oral cavity commonly involved the lateral part of the tongue, floor of the mouth, and adjacent zbadania zależności między zmiennymi posłużono się testem korelacji rang Spearmana. W analizie przyjęto poziom istotności p < 0,05. Analizę statystyczną przeprowadzono za pomocą odpowiednich modułów obliczeniowych pakietu Stata 11.

\section{WYNIKI}

\section{Ocena kliniczna}

Charakterystykę guza nowotworowego oraz zastosowane leczenie w badanej grupie chorych przedstawiono w tabeli 1.

W analizowanej grupie chorych najczęstszym wskazaniem do zabiegu operacyjnego był rak języka (u więcej niż $1 / 4$ badanych). Więcej niż połowa osób operowana była z powodu guza w III i IV stopniu zaawansowania klinicznego, $2 / 3$ chorych poddano leczeniu operacyjnemu z następową radioterapią. Zakres zabiegu w jamie ustnej najczęściej obejmował boczną część języka, dna jamy ustnej i przyległą część żuchwy (u prawie 1/5

TABLE 1. Tumour characteristic and medical treatment

TABELA 1. Charakterystyka guza nowotworowego i leczenie

\begin{tabular}{|c|c|}
\hline $\begin{array}{l}\text { Tumour characteristic } \\
\text { Charakterystyka nowotworu }\end{array}$ & $\begin{array}{l}\text { Number of cases } \\
\text { Liczba chorych }\end{array}$ \\
\hline $\begin{array}{l}\text { Tumour site: / Umiejscowienie: } \\
\text { maxilla / szczęka } \\
\text { floor of mouth / dno jamy ustnej } \\
\text { oral tongue / język } \\
\text { oropharynx / gardło } \\
\text { upper inferior alveolus / dziąsło dolne } \\
\text { palate / podniebienie }\end{array}$ & $\begin{array}{l}8 \\
26 \\
28 \\
5 \\
23 \\
10\end{array}$ \\
\hline $\begin{array}{l}\text { Tumour stage: / Zaawansowanie kliniczne: } \\
\text { early tumour (TI and TII) / wczesne stadia (TI i TII) } \\
\text { late tumour (TIII and TIV) / późne stadia (TIII i TIV) }\end{array}$ & $\begin{array}{l}43 \\
57\end{array}$ \\
\hline $\begin{array}{l}\text { Treatment modalities: / Leczenie: } \\
\text { surgery only / chirurgiczne } \\
\text { surgery and radiotherapy / chirurgiczne + radioterapia }\end{array}$ & $\begin{array}{l}33 \\
67\end{array}$ \\
\hline $\begin{array}{l}\text { Range of surgery: / Zakres wycięcia tkanek jamy ustnej: } \\
\text { 1. Oral cavity front (mandible, floor of mouth, tip of the tongue) / Przednia część jamy ustnej (żuchwa, dno jamy } \\
\text { ustnej, spodnia częś języka) } \\
\text { 2. Lateral part of the oral cavity (mandible, floor of mouth, tongue - to the mid-line) / Boczna część jamy ustnej } \\
\text { (żuchwa, dno jamy ustnej, język do linii środkowej) } \\
\text { 3. Middle part of the oral cavity (part of the tongue or almost all of it) / Środkowa część jamy ustnej (część języka lub } \\
\text { prawie cały język) } \\
\text { 4. Posterior-lateral part of the oral cavity (palatine tonsil, root of the tongue, mandible branch) / Tylno-boczna część } \\
\text { jamy ustnej (migdałek podniebienny, nasada języka, gałąż żuchwy) } \\
\text { 5. Upper part of the oral cavity (palate, jaw) / Górna część jamy ustnej (podniebienie i szczęka) } \\
\text { 6. The excision exceeds designated borders / Wycięcie przekracza zakreślone granice }\end{array}$ & $\begin{array}{c}6 \\
30 \\
24 \\
17 \\
8 \\
15\end{array}$ \\
\hline $\begin{array}{l}\text { Type of reconstruction: / Zaopatrzenie rany poresekcyjnej, ewentualna rekonstrukcja: } \\
\text { excision and primary closure / zbliżenie i pierwotne zszycie brzegów } \\
\text { reconstructive splint / szyna rekonstrukcyjna } \\
\text { obturator / proteza - obturator } \\
\text { regional flaps / płaty regionalne } \\
\text { complex and Free vascular flaps / złożone płaty i wolne płaty }\end{array}$ & $\begin{array}{c}28 \\
11 \\
8 \\
40 \\
13\end{array}$ \\
\hline
\end{tabular}

RND - radical neck dissection / układ chłonny szyi 
TABLE 2. Tumour characteristics and medical treatment

TABELA 2. Wybrane funkcje oceniane po wycięciu nowotworu jamy ustnej

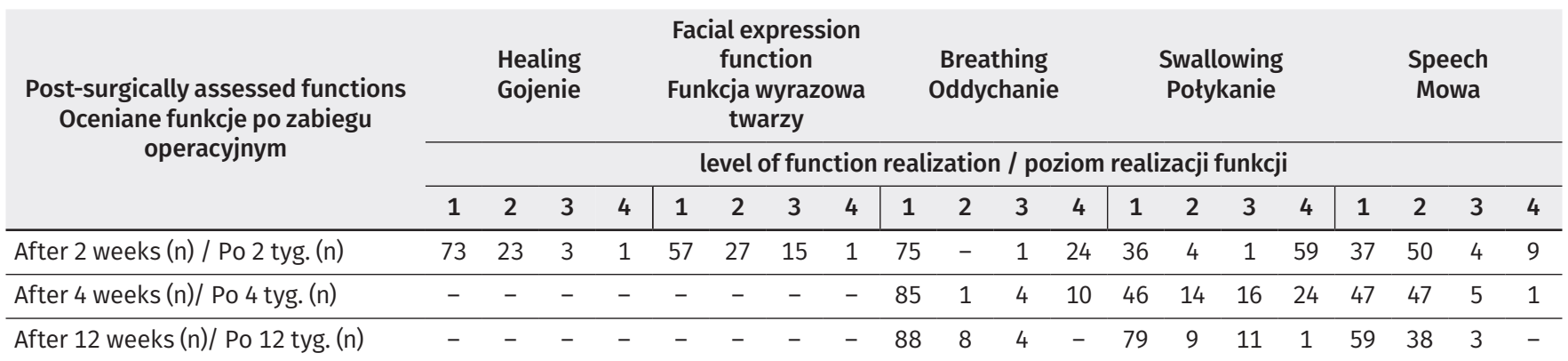

Level of function realization: Healing - 1) primary intention; 2) inflammation, marginal necrosis; 3) necrosis, partial loss of the tissues used for reconstruction; 4) removal of the transplant. Facial expression functions - 1) lack of distortions; 2) minor distortions, preserved expression functions; 3 ) distortions visible at rest and during functioning; 4) disturbed symmetry, vertical proportions of the face, and expression functions. Breathing - 1) free; 2) in certain positions; 3 ) with effort and the use of additional respiratory muscles; 4) tracheostomy. Swallowing - 1) effective; 2) in certain positions, coughing; 3 ) coughing during swallowing, swallowing is inefficient; 4) tube. Speech - 1) intelligible; 2) distorted but intelligible; 3) significantly distorted, difficult to understand; 4) written communication Poziom realizacji funkcji: Gojenie - 1) rychłozrost; 2) odczyn zapalny, brzeżna martwica; 3) martwica, częściowa utrata tkanek użytych do rekonstrukcji; 4) usunięcie przeszczepu. Funkcja wyrazowa twarzy - 1) brak zniekształceń; 2) nieznaczne zniekształcenia, zachowane funkcje wyrazowe; 3) zniekształcenia widoczne w spoczynku i podczas funkcji; 4) zaburzona symetria, pionowe proporcje twarzy i funkcje wyrazowe. Oddychanie - 1) swobodne; 2) w wybranej pozycji; 3) z wysitkiem, użyte dodatkowe mięśnie oddechowe; 4) tracheostomia. Połykanie - 1) efektywne; 2) w określonej pozycji, odkrztusza; 3) kaszle przy połykaniu, połykanie nie jest sprawne; 4) sonda. Mowa - 1) zrozumiała; 2) zniekształcona, ale zrozumiała; 3) znacząco zniekształcona, trudna do zrozumienia; 4) pisana

parts of the mandible (in almost $1 / 5$ of the patients); the range of surgery within the neck was mostly modified lymphangiectomy (in $1 / 3$ of the patients). Reconstruction performed in the greatest number of the patients (40) was based on regional flaps; complex flaps and free flaps with microsurgery were used more rarely.

In the early post-surgical period, which included the first 2 weeks after the surgery, wound healing without any complications was observed in the majority of the patients (74). The most common obstacle in proper wound healing was inflammation and marginal tissue necrosis.

Face distortion was associated mostly with excessive excision of stomatognathic system structures, but also with complicated wound healing. Face expression function was preserved in 79 of the patients, in spite of distortions in 32 of the patients. Face distortion visible during relaxation and activity was diagnosed in 21 of the patients.

During the period of 2,4 , and 12 weeks after oral cavity neoplasm excision, the maintenance of some important life functions, i.e. comfortable breathing, natural swallowing, and intelligible speech, was thoroughly assessed in all of the patients. The data are shown in Table 2.

\section{Self-image, body image and illness acceptance characteristics}

Mean values for particular scales of ACL-37 scored in the group of patients are shown in Figure 1.

In the self-image profile of the patients with neoplasm all of the average values of the ACL-37 scales were between 40 and 54 points of strict outcomes. None of the scales scored high scores. Low scores were scored by the patients in the following scales: total number of chosen adjectives (NCK), commoness (COM), need for heterosexual contact (HET), need for change (CHA), and high originality, low intelligence (A-1).

Basic descriptive statistics (mean, median, minimum, maximum, standard deviation) for the variables describing the level chorych), zakres zabiegu na szyi był najczęściej zmodyfikowaną lymphangiectomią ( $\mathrm{u}^{1}$ / 3 chorych). Podjęta rekonstrukcja u największej liczby chorych (40) oparta była na płatach regionalnych, rzadziej stosowane były złożone płaty tkankowe i wolne płaty oparte na mikrozespoleniach naczyniowych.

W okresie wczesnopooperacyjnym obejmującym pierwsze 2 tyg. od zabiegu operacyjnego u większości pacjentów (74 chorych) gojenie przebiegło bez żadnych powikłań. Najczęstszą przeszkodą w prawidłowym gojeniu był odczyn zapalny i brzeżna martwica tkanek. Zniekształcenie twarzy związane było przede wszystkim z rozległym wycięciem struktur układu stomatognatycznego, ale także z powikłanym gojeniem tkanek. Funkcja wyrazowa twarzy pomimo zniekształceń widocznych u 32 pacjentów była zachowana u 79 chorych. Widoczne w spoczynku i podczas funkcji zniekształcenia twarzy stwierdzono u 21 osób.

W okresie 2, 4 i 12 tyg. po wycięciu nowotworu jamy ustnej szczegółowej ocenie u każdego z chorych poddano utrzymanie ważnych dla życia funkcji: swobodnego oddychania, połykania drogą naturalną i zrozumiałej wymowy (tab. 2).

\section{Charakterystyka obrazu siebie, obrazu ciała i akceptacji choroby}

Wartości średnie dla poszczególnych skal Testu Przymiotników ACL-37 uzyskane w badanej grupie chorych przedstawiono na rycinie 1.

W profilu obrazu siebie osób cierpiących z powodu choroby nowotworowej wszystkie średnie wartości skal ACL-37 mieściły się w przedziale wyników surowych 40-54 pkt. W żadnej ze skal nie uzyskano wysokich wyników. Wyniki niskie badani uzyskali w następujących skalach: całkowita liczba wybranych przymiotników (NCK), typowość (COM), potrzeba kontaktów heteroseksualnych (HET), potrzeba zmiany (CHA) oraz wysoka oryginalność, niska inteligencja (A-1).

Podstawowe statystyki opisowe (średnia, mediana, minimum, maksimum, odchylenie standardowe) dla zmiennych 


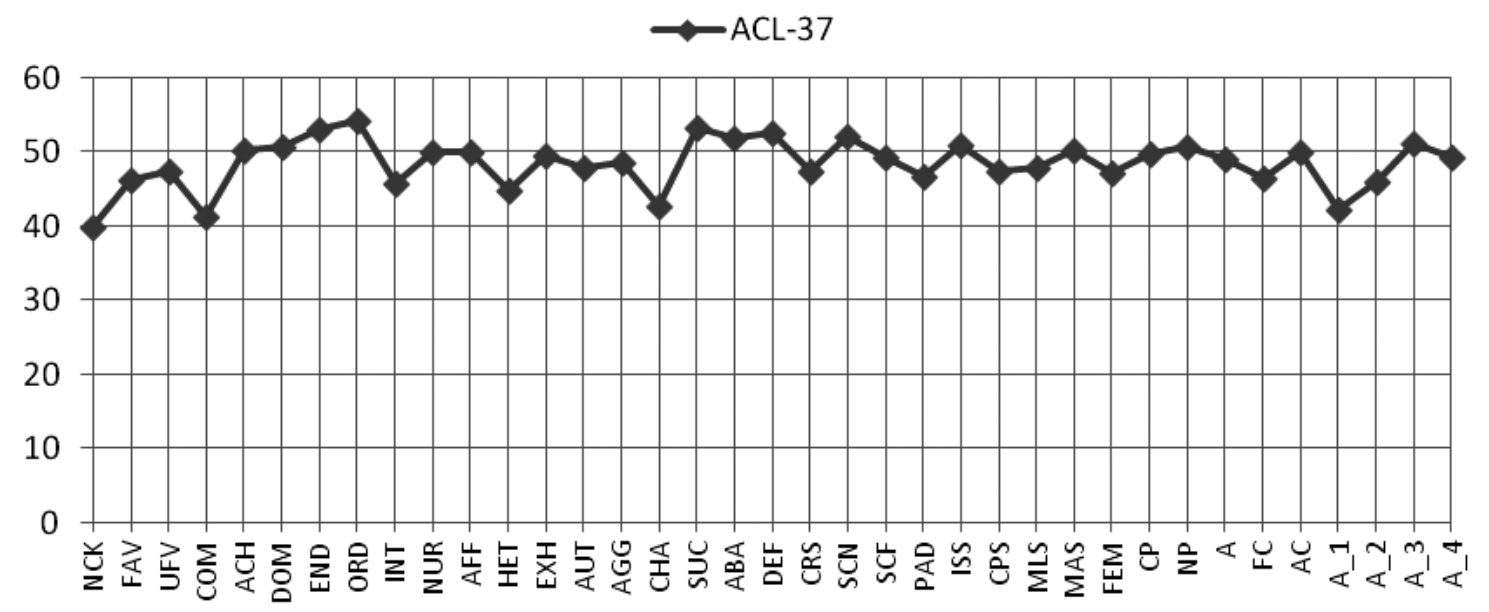

NCK - total number of chosen adjectives / całkowita liczba wybranych przymiotników; FAV - positive adjectives number / liczba przymiotników pozytywnych; UFV - number of unfavourable adjectives checked / liczba zaznaczonych przymiotników negatywnych; COM - commones / typowość; ACH - need for achievments / potrzeba osiągnięć; DOM - need for domination / potrzeba dominacji; END - need for endurance / potrzeba wytrwałości; ORD - need for order / potrzeba porządku; INT - intraception / potrzeba rozumienia siebie i innych; NUR - need for nurturance / potrzeba opiekowania się; AFF - need for affiliation / potrzeba afiliacji; HET need for heterosexual contact / potrzeba kontaktów heteroseksualnych; EXH - need for exhibition / potrzeba ujawniania się; AUT - need for autonomy / potrzeba autonomii; AGG - the need for aggression / potrzeba agresji; CHA - need for change / potrzeba zmiany; SUC - the need for succorance / potrzeba wsparcia ze strony innych; ABA - the need for self-abasement / potrzeba poniżania sie; DEF - the need for deference / potrzeba podporzadkowania się; CRS - Counseling Readiness Scale / Gotowość na poradę i pomoc innych; SCN - self-control / samokontrola; SCF - Self-Consistency Field / zaufanie do siebie; PAD - personal adaptation / przystosowanie osobiste; ISS - Ideal Self Scale / skala idealnego obrazu siebie; CPS - creative personality scale / skala osobowości twórczej; MLS - military leadership scale / zdolności przywódcze; MAS - masculinity / męskość; FEM - femininity scale / skala kobiecości; CP - critical parent / krytyczny rodzic; NP - nurturing parent / wychowujący rodzic; A - adult / dorosły; FC - free child / wolne dziecko; AC - adapted child / dziecko przystosowane; A-1 - high originality, low intellectance / wysoka oryginalność, niska inteligencja; A-2 - high origence - high intellectance / wysoka oryginalność, wysoka inteligencja; A-3 - low origence - low intellectance / niska oryginalność, niska inteligencja; A-4 - low origence, high intellectance / niska oryginalność, wysoka inteligencja

FIGURE 1. Mean values of Adjective Check List ACL-37 scales

RYCINA 1. Średnie wartości skal Testu Przymiotników ACL-37

TABLE 3. Body satisfaction and body importance in the assessed group - basic statistics TABELA 3. Satysfakcja z ciała i znaczenie ciała w badanej grupie - podstawowe statystyki

\begin{tabular}{|c|c|c|c|c|c|}
\hline $\begin{array}{l}\text { Body image variables } \\
\text { Zmienne obrazu ciała }\end{array}$ & $\begin{array}{l}\text { Average } \\
\text { Średnia }\end{array}$ & $\begin{array}{l}\text { Median } \\
\text { Mediana }\end{array}$ & Minimum & $\begin{array}{l}\text { Maximum } \\
\text { Maksimum }\end{array}$ & SD \\
\hline BCS1 / KOC1 & 3.58 & 3.52 & 2.57 & 4.80 & 0.47 \\
\hline BCS1_Functions / KOC1_Funkcje & 3.64 & 3.75 & 1.63 & 5.00 & 0.62 \\
\hline BCS1_Parts / KOC1_Części & 3.48 & 3.45 & 2.45 & 4.73 & 0.48 \\
\hline BCS1_Face / KOC1_Twarz & 3.47 & 3.50 & 2.07 & 4.79 & 0.60 \\
\hline BCS2 / KOC2 & 3.80 & 3.78 & 2.30 & 5.00 & 0.52 \\
\hline BCS2_Functions / KOC2_Funkcje & 4.26 & 4.25 & 2.50 & 5.00 & 0.48 \\
\hline BCS2_Parts / KOC2_Części & 3.82 & 3.93 & 1.62 & 5.24 & 0.68 \\
\hline BCS2_Face / KOC2_Twarz & 3.80 & 3.79 & 2.00 & 5.00 & 0.60 \\
\hline
\end{tabular}

of body satisfaction (BCS1) and body importance (BCS2) in the group of patients are presented in Table 3 .

In the analyzed group of patients the level of body satisfaction - in the general aspect (BCS 1 ) as well as body function (BCS1_Functions), and appearance of particular body parts (BCS1_Parts) or face (BCS1_Face) - oscillated around 3.5 points, between the neutral and satisfactory categories. By contrast, the level of body significance for the patients was slightly greater and scored 3.8 points for all of the analyzed body aspects except for body functions, which was assessed by the patients as more than important ( 4.26 points).

In the assessed grop of patients the level of illness acceptance was moderate - the average of the AIS test was 27.71 points, with a standard deviation of 8.05 . opisujących poziom satysfakcji z ciała (KOC1) oraz znaczenia ciała (KOC2) w badanej grupie chorych zawarto w tabeli 3.

$\mathrm{W}$ analizowanej grupie poziom zadowolenia $\mathrm{z}$ ciała i to zarówno w aspekcie ogólnym (KOC1), jak i funkcjonowania ciała (KOC1_Funkcje) oraz wyglądu poszczególnych części ciała (KOC1_Części) czy twarzy (KOC1_Twarz) - oscylował wokół wartości 3,5 pkt, a więc między kategorią neutralności i zadowolenia. Z kolei poziom znaczenia przypisywanego ciału przez chorych był nieco wyższy i wynosił ok. 3,8 pkt dla wszystkich analizowanych aspektów cielesności z wyjątkiem funkcjonowania ciała, które badani określili jako więcej niż ważne $(4,26$ pkt).

W badanej grupie pacjentów poziom akceptacji choroby był umiarkowany - średnia testu AIS wynosiła 27,71, przy odchyleniu standardowym równym 8,05. 


\section{Personality traits and illness acceptance level versus swallowing and speech}

Spearman's correlation rank was used to examine the correlations between personality traits and swallowing efficiency and intelligibility of speech in the analyzed group of the patients. Table 4 presents statistically significant $r$ correlation indicators of the analysis $(\mathrm{p}<0.05)$.

In the examined group there were significant correlations between time of oesophageal tube maintenance and swallowing efficiency, and chosen body image and self-mage of the patients' characteristics. Longer time of tube maintenance ( $>2$ weeks) was recorded in the patients with lower body satisfaction level, both in the general aspect (BCS1) and face area (BCS1_Face). What is more, the time of tube maintenance was longer in the patients with lower autonomy need (AUT) and ego condition known as Critical Parent (CP). Less effective swallowing after 4 weeks post-surgically was observed in the patients with a low need for endurance and order, as well as with a lower cognitive nature, which is associated with low originality of thinking with high intelligence (A-4). Greater swallowing efficiency after 12 weeks post-surgically was associated with higher face area satisfaction (BCS1_Face) in the patients, as well as with a lower cognitive nature, associated with low originality and low intelligence (A-3).

In the analyzed group of patients there was correlation between time of written communication and post-surgical speech intelligibility, and some of the self-image characteristics of the patients. Shorter time of written communication

\section{Właściwości osobowości i poziom akceptacji choroby a połykanie i mowa}

Test korelacji rang Spearmana posłużył do zbadania zależności pomiędzy właściwościami psychologicznymi a wydolnością połykania oraz zrozumiałością mowy w analizowanej grupie chorych. Uzyskane w analizie istotne statystycznie $(p<0,05)$ wskaźniki korelacji r zawarto w tabeli 4.

W badanej grupie wystąpiły istotne zależności między czasem utrzymywania sondy przełykowej i wydolnością połykania a wybranymi wskaźnikami obrazu ciała i obrazu siebie badanych. Dłuższy czas korzystania z sondy (>2 tyg.) zarejestrowano u chorych, którzy ujawnili niższy poziom satysfakcji z ciała, i to zarówno w aspekcie ogólnym (KOC1), jak i obszaru twarzy (KOC1_Twarz). Co więcej, czas utrzymywania sondy był dłuższy u osób charakteryzujących się niższym poziomem potrzeby autonomii (AUT) oraz stanem ego określanym jako Krytyczny Rodzic (CP). Mniej prawidłowe połykanie po upływie 4 tyg. od zabiegu zaobserwowano u chorych cechujących się niższą potrzebą wytrwałości (END) i porządku (ORD), a także niższym natężeniem stylu poznawczego łączącego niski poziom oryginalności myślenia z wysokim poziomem inteligencji (A-4). Większa sprawność połykania po upływie 12 tyg. od operacji związana była z wyższym poziomem zadowolenia z obszaru twarzy (KOC1_Twarz) u badanych, jak również niższym natężeniem stylu poznawczego będącego połączeniem niskiej oryginalności i niskiej inteligencji (A-3).

W analizowanej grupie chorych uzyskano również zależności pomiędzy czasem wykorzystywania mowy pisanej oraz zrozumiałością mowy po zabiegu operacyjnym a niektórymi

TABLE 4. Personality traits versus swallowing and speech in the examined group of patients

TABELA 4. Właściwości osobowości a połykanie i mowa w badanej grupie chorych

\begin{tabular}{|c|c|c|c|c|c|c|}
\hline $\begin{array}{l}\text { Psychological variables } \\
\text { Zmienne psychologiczne }\end{array}$ & $\begin{array}{c}\text { Time of } \\
\text { oesophageal } \\
\text { intubation } \\
\text { Czas } \\
\text { utrzymywania } \\
\text { sondy } \\
\text { przełykowej }\end{array}$ & $\begin{array}{l}\text { Swallowing } \\
\text { after } 4 \text { weeks } \\
\text { Połykanie } \\
\text { po upływie } \\
4 \text { tyg. }\end{array}$ & $\begin{array}{l}\text { Swallowing } \\
\text { after } 12 \text { weeks } \\
\text { Połykanie } \\
\text { po upływie } \\
12 \text { tyg. }\end{array}$ & $\begin{array}{c}\text { Time of written } \\
\text { communication } \\
\text { use } \\
\text { Czas } \\
\text { posługiwania } \\
\text { się mową } \\
\text { pisaną }\end{array}$ & $\begin{array}{c}\text { Speech after } \\
4 \text { weeks } \\
\text { Mowa } \\
\text { po upływie } \\
4 \text { tyg. }\end{array}$ & $\begin{array}{c}\text { Speech after } \\
12 \text { weeks } \\
\text { Mowa } \\
\text { po upływie } \\
12 \text { tyg. }\end{array}$ \\
\hline BCS1 / KOC1 & -0.26 & & & & & \\
\hline BCS1_Face / KOC1_Twarz & -0.37 & & -0.23 & & & \\
\hline $\begin{array}{l}\text { Need for endurance } \\
\text { Potrzeba wytrwałości }\end{array}$ & & -0.26 & & & & \\
\hline $\begin{array}{l}\text { Need for order } \\
\text { Potrzeba porządku }\end{array}$ & & -0.30 & & & & -0.27 \\
\hline $\begin{array}{l}\text { Need for exhibition } \\
\text { Potrzeba ujawniania się }\end{array}$ & & & & -0.71 & & \\
\hline $\begin{array}{l}\text { Femininity scale } \\
\text { Skala kobiecości }\end{array}$ & & & & & & 0.23 \\
\hline $\begin{array}{l}\text { Critical parent } \\
\text { Krytyczny rodzic }\end{array}$ & -0.28 & & & -0.74 & & \\
\hline $\begin{array}{l}\text { Low originality, low intelligence }(A-3) \\
\text { Niska oryginalność, niska inteligencja }(A-3)\end{array}$ & & & 0.23 & & 0.21 & \\
\hline $\begin{array}{l}\text { Low originality, high intelligence }(A-4) \\
\text { Niska oryginalność, wysoka inteligencja }(A-4)\end{array}$ & & -0.27 & & & & \\
\hline $\begin{array}{l}\text { Acceptance of Illness Scale } \\
\text { Skala Akceptacji Choroby }\end{array}$ & & & & & -0.25 & \\
\hline
\end{tabular}


use was accompanied by higher need for exhibition and CP scale. Worse speech intelligibility 4 weeks post-surgery was accompanied by lower illness acceptance (AIS), and higher cognitive nature level defined as low originality, low intelligence (A-3). Patients with better speech intelligibility after 12 weeks post-surgery showed a greater need for order (ORD) and a lower femininity level (FEM).

A significant correlation between the level of illness acceptance (AIS) and intelligibility of speech was assessed 4 weeks post-surgery; patients whose speech was more efficient accepted their illness better.

\section{Personality traits and face distortion}

Associations between face distortion level and personality traits of the patients were also analyzed with Spearman's correlation rank order. Statistically significant results $(p<0.05)$ are presented in Table 5 .

TABLE 5. Personality traits and face distortion in the analyzed group TABELA 5. Właściwości osobowości a zniekształcenie twarzy w badanej grupie

\begin{tabular}{ll}
\multicolumn{1}{c}{$\begin{array}{c}\text { Test variables Adjective Check List ACL-37 } \\
\text { Zmienne Testu Przymiotników ACL-37 }\end{array}$} & $\begin{array}{c}\text { Face distortion } \\
\text { Znieksztatcenie }\end{array}$ \\
\hline $\begin{array}{l}\text { Positive adjectives number } \\
\text { Liczba przymiotników pozytywnych }\end{array}$ & -0.23 \\
\hline $\begin{array}{l}\text { Need for achievements } \\
\text { Potrzeba osiągnięć }\end{array}$ & -0.23 \\
\hline $\begin{array}{l}\text { Need for domination } \\
\text { Potrzeba dominacji }\end{array}$ & -0.32 \\
\hline $\begin{array}{l}\text { Need for endurance } \\
\text { Potrzeba wytrwałości }\end{array}$ & -0.27 \\
\hline $\begin{array}{l}\text { Need for exhibition } \\
\text { Potrzeba ujawniania się }\end{array}$ & -0.22 \\
\hline $\begin{array}{l}\text { Counselling Readiness Scale } \\
\text { Gotowość na poradę i pomoc innych }\end{array}$ & 0.23 \\
\hline $\begin{array}{l}\text { Self-Consistency Field } \\
\text { Zaufanie do siebie }\end{array}$ & -0.29 \\
\hline $\begin{array}{l}\text { Ideal Self Scale } \\
\text { Skala idealnego obrazu siebie }\end{array}$ & -0.23 \\
\hline $\begin{array}{l}\text { Free Child } \\
\text { Wolne dziecko }\end{array}$ & \\
\hline
\end{tabular}

Some of the self-image characteristics were associated with the level of face distortion. Patients in whom post-surgical face distortion was higher gave a shorter list of positive adjectives of themselves (FAV), and they got lower scores on needs scales, e.g. achievements (ACH), domination (DOM), endurance (END) and exhibition (EXH), as well as self-consistency (SCF) and ideal self-image (ISS). At the same time, the aforementioned patients got higher scores on the scale describing counselling readiness (CRS).

\section{DISCUSSION}

The outcomes of the research show that various personality traits of the patients are associated with their achievements in wskaźnikami obrazu siebie pacjentów. Krótszemu czasowi używania mowy pisanej towarzyszyło wyższe natężenie potrzeby ujawniania się oraz stanu ego określanego jako Krytyczny Rodzic. Gorszej zrozumiałości mowy 4 tyg. po zabiegu operacyjnym towarzyszyło wyższe natężenie stylu poznawczego definiowanego jako niska oryginalność, niska inteligencja (A-3). Chorzy prezentujący lepszą zrozumiałość mowy po upływie 12 tyg. od zabiegu operacyjnego ujawnili większą potrzebę porządku (ORD) oraz niższy poziom kobiecości (FEM).

Istotną zależność uzyskano pomiędzy poziomem akceptacji choroby a zrozumiałością mowy ocenianą 4 tyg. po operacji osoby, które sprawniej posługiwały się mową, w większym stopniu akceptowały swoją chorobę.

\section{Właściwości osobowości a znieksztatcenie twarzy}

Zbadano również zależności pomiędzy poziomem zniekształcenia twarzy a właściwościami osobowości chorych, posługując się testem korelacji rang Spearmana. Istotne wyniki $(p<0,05)$ zawarto w tabeli 5 .

Z poziomem zniekształcenia twarzy u badanych związane były niektóre właściwości ich obrazu siebie. Osoby, u których zniekształcenie twarzy po zabiegu operacyjnym było większe, opisywały siebie mniejszą liczba przymiotników pozytywnych (FAV), uzyskiwały niższe wyniki w skalach potrzeb: osiągnięć $(\mathrm{ACH})$, dominacji (DOM), wytrwałości (END) i ujawniania się (EXH), oraz w skali zaufania do siebie (SCF) i idealnego obrazu siebie (ISS); jednocześnie osoby te uzyskiwały wyższe wyniki w skali opisującej gotowość na poradę i pomoc innych (CRS).

\section{DYSKUSJA}

Uzyskane wyniki wskazują, że na różnych etapach rehabilitacji połykania i mowy odmienne właściwości osobowości osób chorych związane są z pozytywnymi osiągnięciami. Większą wydolność połykania ocenianą po okresie więcej niż 12 tyg. od zabiegu operacyjnego zaobserwowano u chorych uzyskujących niższe wyniki w skali A-3, a więc u osób inteligentnych i twórczych, ale jednocześnie niespokojnych, skrępowanych, $\mathrm{z}$ tendencją do zamartwiania się, a w relacjach interpersonalnych zdystansowanych, sceptycznych, mających skłonność do odczuwania wyalienowania.

Po upływie 4 tyg. od operacji gorsza wydolność połykania występowała u osób w mniejszym stopniu przejawiających potrzeby porządku oraz wytrwałości i uzyskujących niższe wyniki w skali A-4, co wskazuje na trudność w kontrolowaniu siebie i mobilizowaniu do długotrwałego wysiłku (koniecznego do realizacji odległego celu), a zamiast tego poszukiwaniu natychmiastowej gratyfikacji, łatwości rozpraszania się i zmiany kierunku działania, poddawania się impulsom.

Na podstawie uzyskanych wyników można sądzić, że podejmowanie przez pacjenta większego wysiłku rehabilitacji może być niekiedy motywowane doświadczaniem napięcia w kontaktach z innymi, obawą przed byciem nieakceptowanym przez innych, co może łączyć się z wysokimi oczekiwaniami wobec własnej osoby. 
swallowing and speech rehabilitation at various stages. Greater swallowing efficiency after more than 12 weeks post-surgically was observed in patients with lower scores on the A-3 scale, i.e. patients were intelligent and creative, but at the same time anxious and discomforted, with a tendency to worry, and to be detached, sceptical and vulnerable to a sense of alienation in interpersonal relations.

Worse swallowing efficiency 4 weeks post-surgery was present in patients with lower needs for order and endurance, and lower scores on the A-4 scale, which indicates difficulties with self-control, and long-lasting effort mobilization (which is necessary for the long-term goals realization); instead of these, patients looked for immediate gratification, they had difficulties with concentration and change of the action direction, and they were also impulsive.

The results suggest that taking up the effort of rehabilitation by a patient may sometimes be motivated by tension about contact with others, or fear of being unaccepted by others, which may be associated with high levels of self-expectancy.

Time of post-surgical written communication use was longer in patients with a lesser need for exhibition and with lower CP scale scores, which is characteristic for people who are cautious in their social relations, slowed down, reluctant to selfexhibit, as well as tolerant towards others, and willing to avoid interpersonal conflicts, even for the price of submission. Worse speech intelligibility after 4 weeks post-surgically was accompanied with higher cognitive nature intensity determined as low originality, low intelligence (A-3), characteristic for people who are patient, non-complicated, open, and accepting their own social roles. However, speech intelligibility after 12 weeks post-surgery was better in patients characterized by a greater need for order as well as a lower femininity level, i.e. people focused on standing alone, planned and intended action based on rational and objective premises, with a critical attitude to life, detached, and not eager for change. It may be assumed that the complex of personality traits indicating social withdrawal and an accepting attitude to reality made the patients vulnerable to self-adaptation to the situation, rather than attempting to overcome their condition. However, the need for affecting the environment (making an impression on others, affecting others or withstanding) will be a motivating rehabilitation factor, which is accompanied by the sense of insecurity, or even social alienation and a need for self-dependency.

Unexpectedly, the level of body deformity was not associated with the image of the patients' body (nor with the level of bodily satisfaction, or the level of significance of various bodily aspects). However, it was associated with some elements of self-image. Greater face deformity was accompanied with showing more often certain psychological functioning manners, such as: anxiety in terms of the future, fed up and overwhelming sensation in terms of any life obstacles, self-denial as a result of low self-esteem; lack of self-esteem and competition, or exhibition avoidance of demanding situations; changeability, lack of focus or change in action direction; caution, slow down, tendency for interpersonal conflicts avoidance, and vulnerability to others, reluctance of exhibition causing a lack of
Czas posługiwania się mową pisaną po operacji był dłuższy u chorych przejawiających w mniejszym stopniu potrzebę ujawniania się oraz uzyskujących niższe wyniki w skali CP, co charakteryzuje osoby, które w kontaktach społecznych są ostrożne i zahamowane, niechętne do eksponowania siebie, a zarazem tolerancyjne wobec innych i skłonne do unikania konfliktów interpersonalnych nawet za cenę uległości. Gorszej zrozumiałości mowy ocenianej po upływie 4 tyg. od zabiegu operacyjnego towarzyszyło wyższe natężenie stylu poznawczego określanego jako niska oryginalność, niska inteligencja (A-3), charakteryzującego osoby cierpliwe, nieskomplikowane, otwarte, respektujące role społeczne i swoją rolę w życiu. Z kolei zrozumiałość mowy po upływie 12 tyg. od operacji była lepsza u chorych cechujących się większą potrzebą porządku, a zarazem niższym poziomem kobiecości, a więc nastawionych na samodzielne, planowe i celowe działanie prowadzone w oparciu o racjonalne i obiektywne przesłanki, o krytycznym nastawieniu do rzeczywistości, zdystansowanych, nielubiących zmian. Można podejrzewać, że zespół właściwości osobowości wskazujący na wycofanie społeczne oraz akceptującą postawę wobec rzeczywistości skłaniał badanych chorych raczej do przystosowania się do zaistniałej sytuacji niż podejmowania prób przezwyciężenia swojego stanu, natomiast czynnikiem motywującym do rehabilitacji będzie potrzeba oddziaływania na otoczenie (wywierania na innych wrażenia, wpływania na nich albo przeciwstawia się im), której towarzyszy poczucie niepewności, a nawet wyalienowania społecznego oraz pragnienie polegania na sobie.

Nieoczekiwanie stopień zniekształcenia ciała nie był związany z obrazem ciała badanych (ani z poziomem zadowolenia $\mathrm{z}$ ciała, ani z poziomem znaczenia przypisywanego różnym aspektom cielesności), natomiast związany był z niektórymi elementami obrazu siebie. Większemu zniekształceniu twarzy towarzyszyło częstsze przejawianie takich sposobów funkcjonowania psychicznego, jak: lękowe nastawienie do przyszłości, poczucie zniechęcenia i przytłoczenia w zetknięciu z przeciwnościami losu, zaprzeczanie sobie jako wynik niskiej samooceny; brak pewności siebie i unikanie sytuacji wymagających współzawodnictwa lub eksponowania własnej osoby; zmienność, łatwość rozpraszania się i zmieniania kierunku działania; ostrożność, zahamowanie, tendencja do unikania konfliktów interpersonalnych i ulegania innym, niechęć do eksponowania siebie wynikająca z braku zaufania do siebie; trudność w mobilizowaniu osobistych zasobów i podejmowaniu działań; poczucie małego sprawstwa w kierowaniu swoim życiem, trudność w ustalaniu i osiąganiu celów, a w kontaktach interpersonalnych dbałość o samopoczucie innych; ostrożność w relacjach interpersonalnych, powolność $\mathrm{w}$ reakcjach, umiarkowanie. Jednocześnie większemu zniekształceniu twarzy towarzyszyła większa potrzeba uzyskiwania poradnictwa wynikająca z braku satysfakcji ze swego położenia i pragnienia jego zmiany. W niniejszym badaniu poziom zniekształcenia u większości pacjentów był nieznaczny, jednak uzyskane wyniki zgodne są z innymi doniesieniami wskazującymi, iż zmieniony wygląd twarzy jest dla pacjentów cierpiących z powodu nowotworu głowy i szyi źródłem 
self-trust; difficulties in personal resources mobilization and taking action; sense of low causation in their own life control, difficulties in setting and achieving goals, and concern for others' mood in interpersonal contacts; caution in interpersonal relations, slowness in reactions, temperance. At the same time greater face deformity was accompanied by a greater need for counselling caused by lack of life-position satisfaction and will to change it. In the research the level of face deformity in the majority of the patients was not significant. However, the results are in compliance with other reports showing that changed face appearance is for the patients affected by head and neck tumour a source of many different psychological difficulties, which have the same denominator - fear of social rejection and lack of self-esteem.

In the research of Fingeret et al. concerning body image, which was conducted among patients with oral cavity cancer waiting for surgery, $77 \%$ of them experienced anxiety due to current facial appearance, or were afraid of post-surgical deformities [22]. In other research, the level of deformity associated with experienced anxiety and depression level was assessed by the patients with oral cavity tumour [23]. Very high levels of anxiety, as well as low levels of coping with stress was shown by patients with head and neck cancer waiting for disfigurative surgery in the research conducted by Dropkin [24]

It is worth emphasizing that the way in which patients experience deformities of their own body may be shaped by their personality traits. In the research by Hagedoorn and Molleman in a group of 76 patients affected by head and neck cancer, the level of face deformity was positively correlated with anxiety and negative emotions experienced due to the uncomfortable behaviour of others only in patients with a low sense of social self-efficacy. Patients with a high level of the feature (defined as the ability to possess control in social contacts) did not experience the aforementioned psychological difficulties, independently of subjectively perceived facial deformity level [12].

An association between bodily satisfaction and swallowing assessment in the patients was shown in the assessed group. Less body satisfaction in the patients, particularly within the face area, was accompanied by longer time of oesophageal tube use, as well as lower swallowing efficiency after 12 weeks postsurgery. In our opinion, there are at least two explanations for this association. First of all, the result may be interpreted as an effect of self-assessment objectivity in the patients as far as their own body deformity is concerned.

Since the level of face area deformity is mostly associated with the range of tissues excision and wound healing, it could be assumed that a subjective body assessment will correspond with the level of deformity in the patients assessed by the doctors, i.e. patients in whom surgery was less harmful will be able to swallow efficiently, and they will have a more positive attitude to their bodies, particularly their faces (Hagedoorn and Molleman reported moderate and positive correlations between face distortion assessment performed by the patients and the one performed by their doctors) [12]. However, in the assessed group of patients we did not obtain significant correlations between the level of face area distortion and bodily wielu różnych trudności psychologicznych, których wspólną komponentą jest lęk przed odrzuceniem społecznym i poczucie braku wiary w siebie.

W badaniu Fingeret i wsp. nad obrazem ciała przeprowadzonym w grupie pacjentów z nowotworem jamy ustnej oczekujących na operację aż 77\% osób doświadczało niepokoju związanego z aktualnym wyglądem twarzy lub obawiało się zniekształcenia pooperacyjnego [22]. W innym badaniu oceniany przez pacjentów z nowotworem jamy ustnej poziom zniekształcenia był związany z doświadczanym poziomem lęku i depresji [23]. Bardzo wysoki poziom lęku, a także niski poziom radzenia sobie ze stresem był udziałem pacjentów z nowotworem głowy i szyi oczekujących na zniekształcającą operację w badaniu Dropkin [24].

Warto podkreślić, iż sposób doświadczania deformacji własnego ciała może być kształtowany przez cechy osobowości chorych. W badaniu Hagedoorn i Mollemana przeprowadzonym w grupie 76 chorych cierpiących z powodu nowotworu głowy i szyi stopień deformacji twarzy był dodatnio związany z lękiem oraz doświadczaniem negatywnych emocji w odpowiedzi na nieprzyjemne zachowania innych jedynie u osób cechujących się niskim poziomem sprawczości społecznej. Badani o wysokim poziomie tej cechy (rozumianej jako zdolność do pozyskiwania kontroli w kontaktach społecznych) nie doświadczali wymienionych uprzednio trudności psychicznych, niezależnie od subiektywnie postrzeganego stopnia deformacji twarzy [12].

W badanej grupie pacjentów ujawnił się związek pomiędzy satysfakcją z ciała a oceną połykania u chorych. Mniejszemu zadowoleniu z ciała badanych, a w szczególności z obszaru twarzy, towarzyszył dłuższy czas korzystania z sondy przełykowej, jak również mniejsza sprawność połykania po upływie 12 tyg. od operacji. Można uznać, że istnieją co najmniej dwa wyjaśnienia tego związku. Po pierwsze, wynik ten można interpretować jako efekt obiektywności samooceny pacjentów odnośnie do deformacji własnego ciała. Jako że poziom zniekształcenia obszaru twarzy u badanych związany był głównie z zakresem wycięcia tkanek oraz prawidłowością gojenia, można by oczekiwać, iż subiektywna ocena ciała u chorych będzie odpowiadała stopniowi deformacji oszacowanemu przez lekarza, tzn. pacjenci, u których operacja była w mniejszym stopniu okaleczająca, będą mogli połykać bardziej efektywnie, a także będą mieli bardziej pozytywny stosunek do swego ciała, a zwłaszcza twarzy (dodatnią umiarkowaną korelację pomiędzy oceną zniekształcenia twarzy dokonaną przez pacjentów a oceną ich lekarzy uzyskali Hagedoorn i Molleman) [12]. Jednak w badanej grupie nie uzyskano istotnych korelacji pomiędzy stopniem zniekształcenia obszaru twarzy a poziomem satysfakcji z ciała w żadnym z jego aspektów (w tym także satysfakcji z obszaru twarzy). Po drugie, możliwe jest, że większa sprawność połykania była udziałem osób przejawiających większe zadowolenie z ciała, gdyż akceptacja ciała jako przejaw samoopieki łączyła się z większym zaangażowaniem w proces rehabilitacji.

W badaniu Dropkin samoopieka była traktowana jako forma zachowań adaptacyjnych, których składową były zadania pooperacyjne: odsysanie wydzieliny z jamy ustnej, 
satisfaction level in any of its aspects (including satisfactory face area appearance). Secondly, it is possible that greater swallowing efficiency was present in patients who were more satisfied with their bodies because body acceptance as an expression of self-care was associated with greater engagement in the process of rehabilitation.

In the research by Dropkin [9], self-care was treated as a form of coping behaviour, in which post-surgical tasks (oral suctioning, tube feeding, tracheal suctioning) were the components.

The level of illness acceptance (AIS) was associated only with post-surgical speech intelligibility. As can be assumed patients who spoke more comfortably accepted the illness less (among other things they experienced more limitations due to their health condition and greater dependency, and showed lower ability to perform favourite actions).

Research conducted on patients with oral cavity tumours shows that speech quality is particularly important for their functioning. Speech intelligibility impairment is assessed by maxillo-facial surgeons as one of the 19 most serious factors among these patients [25]. Speech impairment in a patient interrupts their communication with the surrounding world and may cause the patient to be perceived as someone with lower social status than their real one [26], or it can cause a sense of alienation in the patient, "being invisible" to others [27]. Experiencing moderate or major difficulties in speech is associated with higher anxiety and depression levels [6].

It is worth emphasizing that in the patients' profile of self-image there was a majority of average results. However, on some of the scales there were some low scores, i.e. NCK, COM, HET, CHA, A-1. Such results indicate inhibition in selfexpression, lack of openness or trust in contact with other people, as well as a tendency to look for stability and routine in life simultaneously with novelty avoidance, or taking some risk. The set of personality traits seems to limit the developmental as well as adaptive possibilities of the patients, making the changes needed in functioning difficult.

Correlations between personality traits and the functional rehabilitation efficiency coefficients of the patients were low or moderate. However, they show the purpose of further research for psychological characteristics that foster the process of rehabilitation. At the same time the results indicate the need for patient's care engagement and the process of their rehabilitation performed by a whole therapeutic team consisting of many, various specialists, among them a psychologist, who should not only support, but also help to build the motivation for rehabilitation and social skills development to ease the adaptation to illness.

\section{CONCLUSIONS}

In the assessed group of patients swallowing efficiency after 4 weeks post-surgery was associated with the need for order and endurance; patients who are focused on order, organization, planned activities, and with a strong sense of obligation karmienie się przez sondę przełykową, odsysanie z rury tracheostomijnej [9].

Poziom akceptacji choroby nowotworowej związany był jedynie ze zrozumiałością mowy po zabiegu operacyjnym. Jak można oczekiwać, osoby, które miały mniejszą swobodę w posługiwaniu się mową, w mniejszym stopniu akceptowały chorobę (m.in. doświadczały więcej ograniczeń wynikających ze stanu zdrowia oraz większej zależności od innych, wskazywały na mniejszą możliwość wykonywania ulubionych czynności).

Z badań prowadzonych wśród pacjentów z nowotworem jamy ustnej wynika, iż jakość mowy ma bardzo duże znaczenie dla ich funkcjonowania. Zrozumiałość mowy wskazywana jest przez chirurgów szczękowo-twarzowych jako jedno z 19 najbardziej typowych zaburzeń w tej grupie pacjentów [25]. Upośledzenie mowy utrudnia komunikację z otoczeniem i może sprawiać, że chory jest odbierany jak ktoś o niższym statusie społecznym niż rzeczywisty [26] albo też wywoływać poczucie wyobcowania, „bycia niewidzialnym” dla innych [27]. Doświadczanie umiarkowanych lub znacznych trudności w posługiwaniu się mową łączy się z wyższym poziomem lęku i depresji [6].

Należy podkreślić, iż w profilu obrazu siebie badanych pacjentów przeważały wyniki przeciętne, ale w kilku skalach uzyskano wyniki niskie - były to: NCK, COM, HET, CHA, A-1. Taki układ wyników wskazuje na zahamowanie w wyrażaniu siebie oraz brak otwartości i zaufania w kontaktach z innymi ludźmi, a także tendencję do poszukiwania w życiu stabilności, rutyny i zarazem unikania nowości czy podejmowania ryzyka. Ten zespół właściwości osobowości wydaje się ograniczać zarówno rozwojowe, jak i adaptacyjne możliwości osób chorych, utrudniając wprowadzanie potrzebnych zmian w sposobie funkcjonowania.

Jakkolwiek uzyskane w badaniu współczynniki korelacji pomiędzy wskaźnikami obrazu siebie, obrazu ciała i poziomem akceptacji choroby nowotworowej a sprawnością połykania, zrozumiałością mowy oraz poziomem zniekształcenia twarzy mieściły się w większości w przedziale wyników od niskich do umiarkowanych, to jednak ujawniają one celowość dalszego poszukiwania psychologicznych właściwości osób chorych sprzyjających procesowi rehabilitacji. Jednocześnie uzyskane wyniki wskazują na potrzebę angażowania w opiekę nad pacjentem i w proces jego rehabilitacji zespołu terapeutycznego złożonego z przedstawicieli różnych specjalności, w tym również psychologa, który powinien z grupy rehabilitowanych chorych wyłonić osoby wymagające szczególnego wsparcia, a także wspomóc pacjentów w zakresie budowania motywacji do rehabilitacji czynnościowej oraz rozwijania umiejętności społecznych ułatwiających adaptację do choroby.

\section{WNIOSKI}

W badanej grupie chorych sprawność połykania po upływie 4 tyg. od operacji była związana z potrzebą porządku i wytrwałości - osoby kładące większy nacisk na uporządkowanie, organizację i planowanie w działaniu i mające silne poczucie obowiązku osiągały lepszą sprawność połykania. Z jakością 
achieved better swallowing efficiency. Satisfaction with the face area was associated with swallowing efficiency soon after the surgery and after finished radiotherapy.

Level of illness acceptance was associated only with speech efficiency achieved in the $4^{\text {th }}$ week post-surgery; patients who achieved greater speech efficiency were more accepting of their illness.

Some of the self-image aspects, i.e. lower intensity of some needs: achievement, domination, endurance and self-exposure, and lesser spontaneity in inter-personal contacts and self-reliance were associated with the level of post-surgical deformity of the patients.

A greater need for counselling due to life change performance also accompanied these aspects.

\section{REFERENCES / PIŚMIENNICTWO}

1. Humphris GM, Ozakinci G. Psychological responses and support needs of patients following head and neck cancer. Int J Surg 2006;4(1):37-44.

2. Woolgar JA, Rogers S, West CR, Errington RD, Brown JS, Vaughan ED. Survival and patterns of reccurrence in 200 oral cancer patients treated by radical surgery and neck dissection. Oral Oncol 1999;35(3):257-65.

3. Deng H, Sambrook PJ, Logan RM. The treatment of oral cancer: an overview for dental professionals. Aust Dental J 2011;56(3):244-52.

4. Day TA, Davis BK, Gillespie MB, Joe JK, Kibbey M, Martin-Harris B, et al. Oral cancer treatment. Curr Treat Options Oncol 2003;4(1):27-41.

5. Shah JP, Gil Z. Current concepts in management of oral cancer - surgery. Oral Oncol 2009;45(4):394-401.

6. Hassanein KA, Musgrove BT, Bradbury E. Functional status of patients with oral cancer and its relation to style of coping, social support and psychological status. Br J Oral Maxillofac Surg 2001;39(5):340-5.

7. Chaturvedi SK, Shenoy A, Prasad KM, Senthilnathan SM, Premlatha BS. Concerns, coping and quality of life in head and neck cancer patients. Support Care Cancer 1996;4(3):186-90.

8. Cunningham SJ. The psychology of facial appearance. Dent Update 1999;26(10):438-43.

9. Dropkin MJ. Anxiety, coping strategies, and coping behaviors in patients undergoing head and neck cancer surgery. Cancer Nurs 2001;24(2):143-8.

10. White C. Body images in oncology. In: Cash T, Pruzinsky T, editors. Body Image. A handbook of theory, research, and clinical practice. New York: The Guilford Press; 2002. p. 379-86.

11. Grossarth-Maticek R, Eysenck H. Personality, smoking, and alcohol as synergistic risk factors for cancer of the mouth and pharynx. Psychol Rep 1990;67:1024-26.

12. Hagedoorn M, Molleman E. Facial disfigurement in patients with head and neck cancer: the role of social self-efficacy. Health Psychol 2006;25(5): 643-7.

13. Osthus AA, Aarstad AKH, Olofsson J, Aarstad H. Head and neck specific Health Related Quality of Life scores predicts subsequent survival in successfully treated head and neck cancer patients: a prospective cohort study. Oral Oncol 2011;47:974-9.

14. Allison P, Guichard C, Fung K, Gilain L. Dispositional optimism predicts survival status 1 year after diagnosis in head and neck cancer patients. J Clin Oncol 2003:21(3):543-48.

15. Dodds WJ, Stewart ET, Logemann JA. Physiology and radiology of the normal oral and pharyngeal phases of swallowing. AJR Am J Roentgenol 1990;154(5):953-63.

16. Dodds WJ, Logemann JA, Stewart ET. Radiologic assessment of abnormal oral and pharyngeal phases of swallowing. AJR Am J Roentgenol 1990;154: 965-74.

17. Juros A, Oleś P. Struktura czynnikowa i skupieniowa Testu Przymiotnikowego ACL G.H. Gougha i A.B. Heilbruna. In: Brzeziński J, Hormowska E, połykania tuż po operacji oraz po zakończeniu radioterapii związana była satysfakcja z obszaru twarzy.

Poziom akceptacji choroby pacjentów był związany jedynie ze sprawnością mowy osiąganą w 4 tyg. od operacji - osoby osiągające większą sprawność mowy bardziej akceptowały chorobę.

Z poziomem zniekształcenia pooperacyjnego badanych związane były niektóre aspekty obrazu siebie - niższe natężenie wybranych potrzeb: osiągnięć, dominacji, wytrwałości i ujawniania siebie, a także mniejsza spontaniczność w kontaktach interpersonalnych i mniejsze zaufanie do siebie. Większemu zniekształceniu twarzy towarzyszyła silniejsza potrzeba uzyskania porady i pomocy innych osób.

editors. Z psychometrycznych problemów diagnostyki psychologicznej. Poznań: Wyd. Nauk. UAM; 1992.

18. Secord PF, Jourard SM. The appraisal of body cathexis: body cathexis and the self. J Consult Psychol 1953;17(5):343-7.

19. Franzoi SL. The body-as-object versus the body-as process: gender differences and gender considerations. Sex Roles 1995;33(5/6):417-37.

20. Zarek A. Obraz ciała w ujęciu procesu lub obiektu a satysfakcja z własnego ciała. Ann Acad Med Stetin 2009;55(1):100-6.

21. Juczyński Z. Narzędzia pomiaru w Promocji i psychologii zdrowia. Warszawa: Pracownia Testów Psychologicznych Polskiego Towarzystwa Psychologicznego; 2001.

22. Fingeret MC, Vidrine DJ, Reece GP, Gillenwater AG, Gritz ER. A multidimensional analysis of body image concerns among newly diagnosed patients with oral cavity cancer. Head Neck 2010;32(3):301-9.

23. Hassanein KA, Musgrove BT, Bradbury E. Psychological outcome of patients following treatment of oral cancer and its relation with functional status and coping mechanisms. J Craniomaxillofac Surg 2005;33(6):404-9.

24. Dropkin MJ. Body image and quality of life after head and neck cancer surgery. Cancer Pract 1999;7(6):309-13.

25. Handschel J, Gellrich NC, Bremerich A, Krüskemper G. Return to work and quality of life after therapy and rehabilitation in oral cancer. In Vivo 2013;27(3):401-7.

26. Pettygrove WB. A psychosocial perspective on the glossectomy experience. J Speech Hear Disord 1985;50(1):107-9.

27. Röing M, Hirsch JM, Holmström I, Schuster M. Making new meanings of being in the world after treatment for oral cancer. Qual Health Res 2009;19(8):1076-86.

\section{KOMENTARZ}

W psychoonkologii koncepcje związane ze związkami osobowości z rakiem powstały w końcówce lat 70. XX w. i bardzo szybko upadły ze względu na brak danych potwierdzających takie założenia i nie powróciły już więcej. Autorzy badania powtarzają w tekście jeszcze raz podobne zdanie: „Z badań wynika, iż cechy osobowości pacjentów wspólnie z innymi czynnikami przyczyniają się do wystąpienia nowotworu jamy ustnej". Jest ono już ostrożniejsze i złagodzone tzw. innymi czynnikami. Słusznie, bo te inne czynniki to uzależnienie od nikotyny i alkoholu, jak pokazuje przypis. Czynniki te muszą wystąpić w połączeniu, żeby można było wysnuć taki wniosek.

dr n. zdr. Monika Tyszkiewicz-Bandur 